\title{
Quantitative assessment of the morphogenetic efficiency in strawberry Fragaria $\times$ ananassa Duch.
}

\author{
Jadwiga Żebrowska, Magdalena Dyduch \\ Department of Genetics and Horticultural Plant Breeding \\ University of Life Sciences in Lublin \\ Akademicka 15, 20-950 Lublin, Poland \\ e-mail: magdadyduch@wp.pl
}

Key words: extranuclear genes, genetic control, inheritance, morphogenetic capability, quantitative parameters, tissue culture

\begin{abstract}
A quantitative assessment of the morphogenetic capability of strawberry was performed. In the experiment, three genotypes of strawberry Fragaria $\times$ ananassa Duch. were tested, including two cultivars: 'Plena' and 'Kent', and one breeding clone no. '394'. Morphogenetic efficiency was expressed by the mean number of microplants produced by the explant of progeny combinations $F_{1}$ in two subsequent subcultures. Progeny $F_{1}$ was obtained after crossings, which were carried out according to Griffing's method 3, with the use of the parental genotypes given above. Quantitative parameters: combining ability and the effect of reciprocal crosses estimated in the progeny $F_{1}$ allowed to assess the genetic control of the analysed feature. The high positive effect of reciprocal crosses showed that in 'Plena' the morphogenetic capability is genetically controlled mainly by nuclear genes. On the other hand, aspects of extranuclear inheritance of the analysed trait were observed in 'Kent', which proved a weak explant ability of the progeny
\end{abstract}


combination $F_{1}$ to produce microplants. This resulted in the high negative effect of reciprocal crosses for that cultivar.

\section{INTRODUCTION}

Today, modern cultivation and plant breeding is based on biotechnological methods. One of these methods is the tissue culture technique, which is the best tool to obtain healthy and highly genetically unified plant material. Such a technique can be developed when the totipotency of a single plant cell had been recognized. This phenomenon enables a process described as morphogenesis. Morphogenesis is an old, and one of the most fascinating fields in biological science and a large number of papers on underlying molecular mechanisms have been published (Ryu-Ichiro 1996). The process of morphogenesis is a natural example of genotype to phenotype mapping (Hoile and Tateson 2000). It is the process of cell division and movement that produces an adult organism from the original single cell (Franklin and Cande 1999, Tateson 2000, Lozovaya et al. 2006). The ability to control the morphogenesis in vitro is very important for developing efficient genetic transformation methods, lowering the cost of micropropagation in developing new crops and in functional genomics studies for testing transgenes in various plant species (Phillips 2004).

In strawberry (Fragaria $\times$ ananassa Duch.), the species which belongs to the Rosaceae family, commercially cultivated to any great extent (Degani et al. 1998), the plant material obtained via tissue culture is commonly used in cultivation and breeding. The morphogenetic potential of cells in this species is expressed at various levels and its inheritance is not yet finally recognised. The efficiency of morphogenesis as a quantitative trait can be simply measured by an average number of microplants produced per explant. The expression of this feature depends on the gene activities determining a cell's capability to create a new, fully organised plant. Knowledge of the genetic control of morphogenetic capacity is very important for devising the best strategy of breeding and cultivation. There are many modes of estimating feature inheritance. In quantitative genetics, the analysis of many crossing combinations, which are realized with the use of various systems, is commonly used to assess the genetic control of a trait. Results of this kind of analysis are described as the general combining ability (GCA) and specific combining ability (SCA) consent to evaluate the usefulness of genotypes for breeding (Gawroński and Żebrowska 2005). In plant cells, the genetic information is distributed among three compartments: the nucleus, the mitochondria and the plastids. Each of these cellular compartments harbours a genome and, consequently, expresses heritable traits. Whereas traits encoded in the nuclear genome are usually inherited according to the Mendelian rules, plastid (cp DNA) 
and mitochondrial (mt DNA) genomes are often transmitted uniparentally (Birky 1995, Hagemann 2002, Barr et al. 2005). Although most studies on the inheritance of some plant traits in different species indicated the predominating significance of nuclear genes, cytoplasmic factors and cytoplasmic $\times$ nuclear interactions were also found to be significant in some studies. However, the relationship between extranuclear and nuclear genes is not well understood at the molecular level (Sugiura 1992, Reboud and Zeyl 1994, Ekiz et al. 1998, Wakasugi et al. 2001). It is believed that cytoplasmic genomes control some valuable agronomic traits. For instance, cpDNA may play a role in the inheritance of some disease resistance (Guo et al. 2000), and mtDNA directly relates to cytoplasmic male sterility (Kumar and Cocking 1987, Schnable and Wise 1998).

Cytoplasmic inheritance can be studied in reciprocal crosses. Differences between reciprocal $F_{1}$ hybrids for the analysed feature are a measure of the importance of the cytoplasm. In order to expand our knowledge of the morphogenetic capability in strawberry and to recognize its genetic control, a quantitative assessment of this feature was performed.

\section{MATERIAL AND METHODS}

A quantitative analysis of morphogenetic efficiency in strawberry was performed. The experiment was carried out in two stages, between April 2005 and June 2006. Three genotypes of strawberry (Fragaria $\times$ ananassa Duch.) were examined, including two cultivars: 'Plena' and 'Kent', and one breeding clone no. '394'. The origin of the genotypes was given below: 'Plena' ['Merton Dawn' $\times$ 'Senga Sengana']; 'Kent' [('Redgauntlet' × 'Tioga') × 'Raritan']; clone no. '394' [('Tioga $\mathrm{S}_{1}$ ' $\times$ 'Cambridge Vigour $\mathrm{S}_{1}$ ') $\times$ 'Dukat']. These genotypes were used as parental forms for crossings that were done according to Griffing's method 3 (Griffing 1956), which included one set of $F_{1} s$ and reciprocals without parents (UbyszBorucka et al. 1985). Griffing's method 3 enabled the estimation in progeny $F_{1}$ such quantitative parameters as the combining ability and effect of reciprocal crosses. The occurrence of a considerably high negative effect of the reciprocal crosses estimated in an offspring testified to the extranuclear inheritance of this feature. The morphogenetic efficiency was expressed by the mean number of microplants produced by the explants of the progeny combinations $F_{1}$ in two subsequent subcultures.

Six groups of progeny $F_{1}$ were used for the analysis, including three combinations $F_{1}$ of single crosses and three combinations $F_{1}$ of reciprocal crosses (Tab. 1). This method of crossing enabled the comparison of mean values of the analysed feature, i.e. the descendant explants' morphogenetic capability in the case of these two types of crossing. In this study, the nuclear inheritance of the 
Table 1. The scheme of crossing, according to Griffing's method 3

\begin{tabular}{|c|c|c|c|c|}
\hline & \multicolumn{3}{|c|}{ Paternal form ${ }^{\lambda}$} \\
\hline & & 'Plena' & 'Kent' & '394' \\
\hline \multirow{3}{*}{$\begin{array}{l}\text { Maternal } \\
\text { form }{ }^{+}\end{array}$} & 'Plena' & & 'Plena' × 'Kent' & 'Plena' x '394' \\
\hline & 'Kent' & 'Kent' $\times$ 'Plena' & & 'Kent' × '394' \\
\hline & ‘394’' & '394' × 'Plena' & '394' × 'Kent' & \\
\hline
\end{tabular}

Table 2. The composition of standard MS medium for strawberry hybrid material stratification and micropropagation

\begin{tabular}{|c|c|c|}
\hline \multirow{2}{*}{ Components $\left(\mathrm{mg} \mathrm{dm}^{-3}\right)$} & \multirow{2}{*}{ Stratification } & Stage of multiplication \\
\hline & & I, II \\
\hline $\mathrm{KNO}_{3}$ & 1900.000 & 1900.000 \\
\hline $\mathrm{KH}_{2} \mathrm{PO}_{4}$ & 170.000 & 170.000 \\
\hline $\mathrm{NH}_{4} \mathrm{NO}_{3}$ & 1650.000 & 1650.000 \\
\hline $\mathrm{MgSO}_{4} \cdot 7 \mathrm{H}_{2} \mathrm{O}$ & 370.000 & 370.000 \\
\hline $\mathrm{CaCl}_{2}$ & 332.200 & 332.200 \\
\hline $\mathrm{H}_{3} \mathrm{BO}_{3}$ & 6.200 & 6.200 \\
\hline $\mathrm{MnSO}_{4} \cdot \mathrm{H}_{2} \mathrm{O}$ & 16.900 & 16.900 \\
\hline FeNaEDTA & 40.300 & 40.300 \\
\hline $\mathrm{CoCl}_{2} \cdot 6 \mathrm{H}_{2} \mathrm{O}$ & 0.025 & 0.025 \\
\hline $\mathrm{ZnSO}_{4} \cdot 7 \mathrm{H}_{2} \mathrm{O}$ & 8.600 & 8.600 \\
\hline $\mathrm{KJ}$ & 0.830 & 0.830 \\
\hline myo-Inositol & 100.000 & 100.000 \\
\hline Nicotinic acid (vit. PP) & - & 0.500 \\
\hline Pirydoxine- $\mathrm{HCl}$ (vit. $\mathrm{B}_{6}$ ) & - & 0.500 \\
\hline Thiamine- $\mathrm{HCl}$ (vit. $\mathrm{B}_{1}$ ) & - & 0.400 \\
\hline Gibberellic acid $\left(\mathrm{GA}_{3}\right)$ & - & 0.010 \\
\hline Indole-3-acetic acid (IAA) & - & 1.000 \\
\hline Benzyl-alpha-pyrene (BAP) & - & 1.000 \\
\hline Agar & 6000.000 & 6000.000 \\
\hline Sucrose & 5000.000 & 20000.000 \\
\hline
\end{tabular}

morphogenetic ability in the Fragaria $\times$ ananassa Duch. was stated on the basis of reciprocal cross value effects. About 60 flower buds on each maternal form were emasculated and then pollinated, with the pollen originating from two paternal forms (30 flower buds on each paternal form). The pollen, obtained from newly opened flowers, was kept for a few days in the Petri dishes in a desiccator at the temperature of $+4^{\circ} \mathrm{C}$. Maternal plants were isolated after pollination. The hybrid material in the form of achenes of the progeny $F_{1}$ was obtained from the fruits collected before reaching full ripeness. The evaluation of the hybrid progeny $F_{1}$ was carried out in the in vitro culture laboratory. The hybrid material was sterilised with sodium hypochlorite for two hours and placed on the MS medium (Murashige and Skoog 1962), without growth regulators, at a restricted sugar concentration of $5 \mathrm{~g} \mathrm{dm}^{-3}$ (Tab. 2). The $\mathrm{pH}$ was adjusted to 5.7. The medium was sterilised in the autoclave at the temperature of $121^{\circ} \mathrm{C}$ for 20 minutes, under the pressure of 
0.1 MPa. The Petri dishes with hybrid combinations $\mathrm{F}_{1}$ were stored for stratification at the temperature $+4^{\circ} \mathrm{C}$ for eight weeks. After the stratification, the dishes were carried into the phytotron (photoperiod $16 \mathrm{~h}$ of light; $8 \mathrm{~h}$ of dark) and the sprouting of the 'seeds' was observed. In order to induce the in vitro morphogenesis, seedlings at the stage of 1-2 leaves were carried on a sterile MS medium with growth regulators (Tab. 2). Each offspring combination $F_{1}$ was represented by at least 40 seedlings that were the replicates as the explants. Their proliferation was observed during the experiment in two subsequent subcultures. The number of microplants produced per a single explant was counted after the first eight weeks of the culture for each offspring combination. In the second passage, 40 explants were proliferated for each progeny combination. One microplant from each proliferated group in the first passage was chosen randomly and was used as an explant in the second subculture. In the experiment, 480 explants were passaged. The obtained results were statistically estimated according to the parameters used for the evaluation of the variation of quantitative traits (Oktaba 1980, Ubysz-Borucka et al. 1985). The variability of the feature was evaluated using such parameters as the variation method, standard deviation and coefficient of variability (Oktaba and Niedokos 1980). Considering the morphogenetic capability in the analysed hybrid combinations, the general combining ability (GCA) of the parental forms as well as the effects of the reciprocal crosses $\left(\mathrm{r}_{\mathrm{ij}}\right)$ were evaluated. A genetic analysis of the statistic components of variation was carried out (Ubysz-Borucka et al. 1985).

\section{RESULTS AND DISCUSSION}

The obtained results showed a significant diversity in the number of microplants created by the explants of six strawberry offspring combinations in two subsequent subcultures.

The average values of the number of microplants per explant obtained for the offspring combination in the first subculture did not differ when compared with the average values obtained in the second subculture. Therefore, it could be suggested that the expression of genes responsible for morphogenetic potential was on a similar level in both subcultures. In this study the mean number of microplants produced by explants of progeny combinations reached the value of 8.0 (Tab. 3). The explants obtained from the crossing of the parental combination 'Plena' $\times$ clone '394' created the highest number of microplants in two subsequent subcultures (12.0). The variability of the number of microplants per explant estimated by the coefficient of variability did not exceed $50 \%$ (Tab. 4), which might indicate a balanced proliferation of meristems in this offspring. In addition, the explants obtained from the parental combination of the 'Plena' and 'Kent' crossing showed a high average number of microplants in two subcultures (Tab. 3), 
at the variability coefficient slightly exceeding $50 \%$ (Tab. 4). The explants obtained from the 'Kent' and clone '394' crossing created the lowest number of microplants in two subcultures (Tab. 3). The variability of the microplant number per explant did not exceed 50\% in this combination (Tab. 4). Explants derived from other combinations of crossings, i.e. 'Kent' $\times$ 'Plena'; clone ' 394 ' $\times$ 'Plena' and clone '394' $\times$ 'Kent', created 8.0, 6.0, and 7.0 microplants, whereas the coefficient of variability did not exceed 50\% in two subcultures (Tabs 3 and 4).

Table 3. Mean number of microplants per explant in six progeny $F_{1}$ and three maternal $\left(\mathrm{y}_{\odot}\right)$ and paternal ( $\left.\mathrm{y}_{\curvearrowright}\right)$ groups in two subcultures

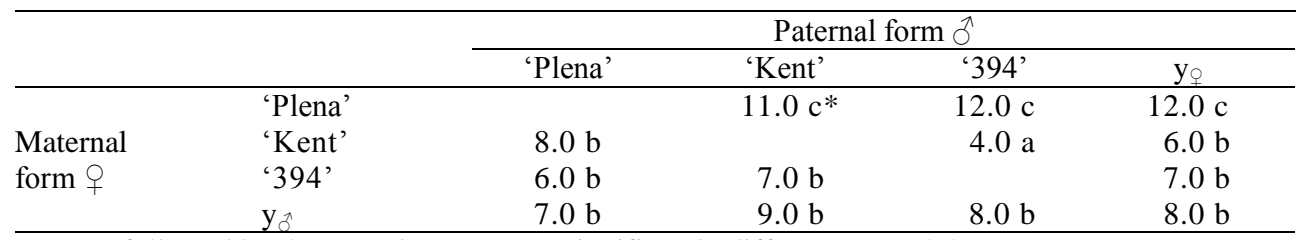

*Means followed by the same letter are not significantly different at $\mathrm{p}=0.05$

Table 4. The variability of morphogenetic efficiency in the progeny $F_{1}$

\begin{tabular}{|c|c|c|c|c|}
\hline \multirow[b]{2}{*}{ No. } & \multirow[b]{2}{*}{ Parental combination } & \multicolumn{3}{|c|}{ Progeny $\mathrm{F}_{1}$} \\
\hline & & $\begin{array}{l}\text { Variance } \\
\left(S^{2}\right)\end{array}$ & $\begin{array}{c}\text { Standard deviation } \\
(\mathrm{S})\end{array}$ & $\begin{array}{c}\text { Coefficient of variability } \\
(\%)\end{array}$ \\
\hline 1 & 'Plena' $\times$ 'Kent' & 35.106 & 5.925 & 53.058 \\
\hline 2 & 'Kent' $\times$ 'Plena' & 13.552 & 3.681 & 48.426 \\
\hline 3 & 'Plena' × '394' & 31.294 & 5.594 & 45.307 \\
\hline 4 & '394' × 'Plena' & 8.142 & 2.853 & 49.615 \\
\hline 5 & 'Kent' × '394' & 2.456 & 1.567 & 43.356 \\
\hline 6 & '394' × 'Kent' & 10.922 & 3.305 & 47.853 \\
\hline
\end{tabular}

In many crossings, where 'Plena' was used as the maternal component, the obtained progeny $F_{1}$ explants produced a high mean number of microplants, whereas the explants of offspring obtained from the crossing between the 'Kent' and clone '394' cultivars created a lower number of microplants per explant in comparison with the average value observed for the total progeny $F_{1}$ (Tab. 3). As a result of the experiment, there were differences in the mean number of microplants obtained from the explants in two subsequent subcultures observed in the offspring $F_{1}$ originating from simple and reciprocal crosses. Therefore, from the perspective of morphogenetic efficiency, it was vital to know which component of the parental combination of crossing had been used as a maternal form (Tab. 3). The average evaluation of the general combining ability (GCA) effects for the examined maternal forms indicated that only the 'Plena' cultivar showed positive effects on GCA. Other maternal forms, i.e. the 'Kent' cultivar and clone '394', gave negative effects of GCA (Tab. 5). A considerably high negative effect of the reciprocal 
crosses $\left(\mathrm{r}_{\mathrm{ij}}\right)$ of morphogenetic efficiency was observed for the combination 'Kent' $\times$ clone ' 394 '. The other analysed combinations, i.e. 'Plena' $\times$ 'Kent' and 'Plena' $\times$ clone '394', showed positive values of this parameter (Tab. 5).

Table 5. The effects of reciprocal crosses $\left(\mathrm{r}_{\mathrm{ij}}\right)$ and general combining ability (GCA) in the analysed progeny $\mathrm{F}_{1}$

\begin{tabular}{|c|c|c|c|c|c|}
\hline & \multicolumn{4}{|c|}{ Paternal form $\hat{\delta}(\mathrm{j})$} \\
\hline & & 'Plena' & 'Kent' & '394' & GCA \\
\hline \multirow{3}{*}{$\begin{array}{l}\text { Maternal } \\
\text { form } \not \text { (i) }\end{array}$} & 'Plena' & & & & 2.662 \\
\hline & 'Kent' & $\mathrm{r}_{\mathrm{ij}}=1.790$ & & & -1.158 \\
\hline & '394' & $\mathrm{r}_{\mathrm{ij}}=3.315$ & $\mathrm{r}_{\mathrm{ij}}=-1.655$ & & -1.503 \\
\hline
\end{tabular}

In quantitative genetics, different models of diallelic crossing are a traditional tool for examining the inheritance of features and are still commonly used, because of the reliability and practical significance for plant breeding and biotechnology. This model of a diallelic cross used in the present study allowed the assessment of the morphogenetic efficiency in strawberry. The parameters of this quantitative trait were genetically estimated after their statistical analysis. Such a mode of evaluation of the morphogenetic potential provided a lot of useful information, expanding our knowledge of strawberry tissue culture based on the phenomenon of morphogenesis. Inheritance of many other quantitative traits in species of angiosperms was examined with this genetic mode of analysis. Modern programs of plant breeding are based on the evaluation of combining ability effects of parental forms, which are crossed to obtain the best hybrid material for selection. Żurawicz et al. (1996) examined in a diallelic cross design the variation and heritability of economically important traits in black currant (Ribes nigrum L.). Mądry et al. (2004) performed a multivariate analysis of breeding and genetic divergence in black currant varieties detected by general combining ability effects. Łuczkiewicz et al. (2004) estimated the influence of morphological differences between inbred lines of sunflower on their specific combining ability effects (SCA) for yield components. Pluta et al. (1994) analyzed some parental forms of Ribes nigrum via diallelic crossing regarding their important useful traits. Prediction of genetic value for coffee production in Coffea arabica from a half-diallel with lines and hybrids was analyzed by Cilas et al. (1998). Brown et al. (1988) used multivariate cross prediction methods in the breeding of a clonally reproduced crop of Solanum tuberosum. Specific combining ability was estimated in tropical maize by Betrán et al. (2003). Finally, Żebrowska (2003) examined the combining ability effects in the progeny of male sterile strawberry.

In the present study, the analysis of reciprocal crosses revealed the cytoplasmic inheritance of morphogenetic potential in the examined strawberry genotypes. Similar results were obtained by Żebrowska and Pacek (2008), who examined the 
influence of plasmogenes on the productivity of morphogenesis in strawberry. The sexual crossing test performed according to Griffing's method 3 allowed the detection of maternal genotypes in which genes determining the morphogenetic efficiency were located in cytoplasmic DNA. Studies carried out by Zhang et al. (2003) confirmed the presence of cytoplasmic DNA in female reproductive cells of the Rosaceae family and defined this mode of cytoplasmic inheritance as maternal. After Correns (1909) and Baur (1909) reported maternal and biparental transmission of leaf colour in angiosperms, these non-Mendelian phenomena have been studied in the intervening years by Sears (1980), Hagemann i Schröder (1989), Kuroiwa (1991), and Mogensen (1996). In spite of decades of research, the modes of cytoplasmic inheritance in angiosperms have been determined for only about 60 genera (Tilney-Bassett 1978, Smith 1988). Still, sexual crossing tests are commonly used to detect the phenomenon of organelle inheritance in plants, because they give an exact result for determining the mode of cytoplasmic inheritance. Recent studies have indicated that inheritance of organelle genomes (plastid and mitochondrial) is controlled in different ways (Nagata et al. 1999, Sodmergen et al. 2002). Therefore, further investigations on cytoplasmic inheritance patterns in angiosperms are required.

\section{CONCLUSIONS}

1. The morphogenetic efficiency in the analysed experimental material considerably varied in the offspring combinations $F_{1}$ and depended on the choice of a maternal component.

2. The best maternal component in the present study was 'Plena', in which the highest morphogenetic efficiency was observed.

3. The lowest morphogenetic efficiency was evaluated for 'Kent', which proved a lower explant ability of the progeny combination $\mathrm{F}_{1}$ to produce microplants.

4. In the analysed material the morphogenetic capability was determined by the nuclear and extranuclear genes.

5. Aspects of nuclear inheritance of the analysed feature were observed for 'Plena', while 'Kent' showed the extranuclear inheritance of this trait.

\section{REFERENCES}

BARR C.M., NEIMAN M., TAYLOR D.R., 2005. Inheritance and recombination of mitochondrial genomes in plants, fungi and animals. New Phytol. 168: 39-50. 
BAUR E., 1909. Das Wesen und die Erblichkeitsverhältnisse der "Varietates albomarginatae hort" von Pelargonium zonale. Z. Indukt. AbstammungsVererbungsl. 1: 330-351.

BETRÁN F.J., RibAut J.M., BECK D., GONZALEZ DE L.D., 2003. Genetic diversity, specific combining ability, and heterosis in tropical maize under stress and nonstress environments. Crop Sci. 43: 797-806.

BIRKY C.J., 1995. Uniparental inheritance of mitochondrial and chloroplast genes: mechanisms and evolution. Proc. Natl. Acad. Sci. USA 92: 11331-11338.

Brown J., Caligari P.D.S., 1988. The use of multivariate cross prediction methods in the breeding of a clonally reproduced crop (Solanum tuberosum). Heredity 60: 147-153.

Cilas C., Bouharmont P., Boccara M., Eskes A.B., Baradat P.H., 1998. Prediction of genetic value for coffee production in Coffea arabica from a halfdiallel with lines and hybrids. Euphytica 104: 49-59.

CORRENS C., 1909. Vererbungsversuche mit blass(gelb)grünen und buntblättrigen sippen bei Mirabilis jalapa, Urtica pilulifera und Lunaria annua. Z. Indukt. Abstammungs-Vererbungsl. 1: 291-329.

DEGANi C., Rowland L.J., LEVI A., HoRTYŃSKi J.A., GALlETTA G.J., 1998. DNA fingerprinting of strawberry (Fragaria $\times$ ananassa) cultivars using randomly amplified polymorphic DNA (RAPD) markers. Euphytica 102: 247-253.

EKIZ H., SAFi KIRAL A., AKCIN A., SimSeK L., 1998. Cytoplasmic effects on quality traits of bread wheat (Triticum aestivum L.). Euphytica 100: 189-196.

FRANKLIN A.E., CANDE W.Z., 1999. Nuclear organization and chromosome segregation. Plant Cell. 11: 523-534.

GAWROŃSKI J., ŻEBROWSKA J., 2005. Ocena zdolności kombinacyjnej wybranych genotypów truskawki (Fragaria $\times$ ananassa Duch.). Część I. Liczba koron, kwiatostanów i kwiatów w kwiatostanie. Ann. Univ. M. Curie-Skłodowska, Sect. EEE, XV, Suppl. 1: 1-8.

GRIFFING B., 1956. A generalised treatment of the use of diallel crosses in quantitative inheritance. Heredity 10: 31-50.

GuO W.W., ZhOU C.H., YI H.L., DENG X.X., 2000. Intergeneric somatic hybrid plants between Citrus and Poncirus trifoliata and evaluation of their root rot resistance. Acta Bot. Sin. 42: 668-672.

Hagemann R., 2002. Milestones in plastid genetics of higher plants. Prog. Bot. 63: 1-51. 
HAGEMANN R., SCHRÖDER M.B., 1989. The cytological basis of the plastid inheritance in angiosperms. Protoplasma 152: 57-64.

Hoile C., TAteson R., 2000. Design by morphogenesis BT. Technol. J. 18(4): 112-121.

Kumar A., CockING E.C., 1987. Protoplast fusion: a novel approach to organelle genetics in higher plants. Am. J. Bot. 74: 1289-1303.

KUROIWA T., 1991. The replication, differentiation, and inheritance of plastids with emphasis on the concept of organelle nuclei. Int. Rev. Cytol. 128: 1-62.

Lozovaya V., Ulanov A., Lygin A., DunCAN D., Widholm J., 2006. Biochemical features of maize tissues with different capacities to regenerate plants. Planta 224: 1385-1399.

ŁUCZKIEWICZ T., KACZMAREK Z., 2004. The influence of morphological differences between sunflower inbred lines on their SCA effects for yield components. J. Appl. Genet. 45: 175-182.

MĄDRY W., KRAJEWSKI P., PluTA S., ŻURAWICZ E., 2004. Multivariate analysis of breeding value and genetic divergence in blackcurrant (Ribes nigrum L.) varieties detected by general combining ability effects. Acta Sci. Pol., Hor. Cult. 3(2): 93-109.

MOGENSEN H.L., 1996. The hows and whys of cytoplasmic inheritance in seed plants. Amer. J. Bot. 83: 383-404.

Murashige T., Skoog F., 1962. A revised medium for rapid growth and bioassays with tobacco tissue cultures. Plant Physiol. 15: 473-497.

Nagata N., Saito C., Sakai A., Kuroiwa H., Kuroiwa T., 1999. The selective increase or decrease of organellar DNA in generative cells just after pollen mitosis one controls cytoplasmic inheritance. Planta 209: 53-65.

OKTABA W., 1980. Elementy statystyki matematycznej i metodyka doświadczalnictwa. PWN, Warszawa: 122-135.

OKTABA W., NiEDOKOS E., 1980. Matematyka i podstawy statystyki matematycznej. PWN, Warszawa: 210-213.

PHILLIPS G.C., 2004. In vitro morphogenesis in plants - recent advances. In Vitro Cell Dev. Biol. Plant. 40: 342-345.

PLUTA S., 1994. Analiza dialleliczna wybranych form rodzicielskich porzeczki czarnej (Ribes nigrum L.) pod względem najważniejszych cech użytkowych. Praca doktorska. Instytut Sadownictwa i Kwiaciarstwa, Skierniewice.

REBOUd X., ZEYL C., 1994. Organelle inheritance in plant. Heredity 72: 132-140. 
RYU-ICHIRO H., 1996. Where am I? How cell recognize its positional information during morphogenesis. Cell Biol. Int. 20(1): 59-65.

SCHNABLE P.S., WISE R.P., 1998. The molecular basis of cytoplasmic male sterility and fertility restoration. Trends Plant Sci. 3(5): 175-180.

SEARS B.B., 1980. Elimination of plastids during fertilization in the plant kingdom. Plasmid 4: 233-255.

SMITH S.E., 1988. Biparental inheritance of organelles and its implication in crop improvement. Plant Breed. Rev. 6: 361-393.

Sodmergen Z.Q., Zhang Y.T., SaKamoto W., Kuroiwa T., 2002. Degradation of mitochondrial genome during sperm cell development in Hordeum vulgare: a mechanism for maternal inheritance of mitochondria in angiosperms. Planta 216: 235-244.

Sugiura M., 1992. The chloroplast genome. Plant Mol. Biol. 19: 149-168.

TATESON R., 2000. The role of development in computational systems. BT Technol. J. 18(4): 85-94.

TILNEY-BASSETT R.A.E., 1978. The inheritance and behavior of plastids. [In:] The Plastids, J.T.O Kirk and R.A.E. Tilney-Bassett (eds). Elsevier, Amsterdam: 251-324.

UbYSZ-BORUCKA L., MĄDRY W., MUSZYŃSKI S., 1985. Podstawy statystyczne genetyki cech ilościowych $\mathrm{w}$ hodowli roślin. Wyd. SGGW, Warszawa: 139-155.

Wakasugi T., Tsudzuki T., Sugiura M., 2001. The genomics of land plant chloroplasts: gene content and alteration of genomic information by RNA editing. Photosynth. Res. 70: 107-118.

ZHANG Q., LiU Y., SODMERGEN Z.Q., 2003. Examination of the cytoplasmic DNA in male reproductive cells to determine the potential for cytoplasmic inheritance in 295 angiosperm species. Plant Cell Physiol. 44(9): 941-951.

ŻEBRowsKA J.I., 2003. Combining ability effects in progeny of male sterile strawberry (Fragaria $\times$ ananasa Duch.). Ann. Univ. M. Curie-Skłodowska, Sectio EEE, XIII: 249-255.

ŻEBROWSKA J., PACEK A., 2008. Influence of plasmogenes on the productivity of morphogenesis in strawberry (Fragaria $\times$ ananassa Duch.). Acta Agrobot. 61(2): 3-10.

ŻURAWICZ E., MĄDRY W., PluTA S., 1996. Variation and heritability of economically important traits in black currant (Ribes nigrum L.) evaluated in diallel cross design. Euphytica 91: 219-224. 


\section{OCENA ILOŚCIOWA WYDAJNOŚCI MORFOGENETYCZNEJ U TRUSKAWKI FRAGARIA $\times$ ANANASSA DUCH.}

Streszczeni e: Celem pracy była ocena ilościowa wydajności morfogenetycznej u truskawki. Testowane były trzy genotypy gatunku Fragaria $\times$ ananassa Duch., w tym dwie odmiany: 'Plena' i 'Kent' oraz jeden klon hodowlany o numerze '394'. Wydajność morfogenetyczną wyrażono średnią liczbą mikroroślin wytworzoną przez eksplantaty kombinacji potomnych $\mathrm{F}_{1} \mathrm{w}$ dwóch kolejnych pasażowaniach kultury. Potomstwo $F_{1}$ otrzymano z krzyżowań wykonanych w oparciu o układ krzyżowania diallelicznego według III. metody Griffinga z użyciem wyżej wymienionych genotypów. Parametry ilościowe: zdolność kombinacyjna i efekty krzyżowań odwrotnych oszacowane $\mathrm{w}$ pokoleniu $\mathrm{F}_{1}$ pozwalają na określenie genetycznych uwarunkowań analizowanej cechy. Wysoki, dodatni efekt krzyżowań odwrotnych wskazuje, że zdolności morfogenetyczne u odmiany 'Plena' są genetycznie kontrolowane głównie przez geny jądrowe. $\mathrm{Z}$ drugiej strony, aspekty dziedziczenia pozajądrowego analizowanej cechy obserwowano u odmiany 'Kent', co przejawiało się słabą zdolnością eksplantatów kombinacji potomnych $\mathrm{F}_{1}$ do wytwarzania mikroroślin. Skutkiem tego były wysokie ujemne efekty krzyżowań odwrotnych odnotowane dla tej odmiany. 